\title{
PERANCANGAN DAN PENGEMBANGAN PRODUK ALAT POTONG SOL SANDAL
}

\author{
Sulung Rahmawan Wiraghani ${ }^{1}$, M Adhi Prasnowo ${ }^{2}$ \\ 1Teknik Industri, Fakultas Teknik \\ Universitas Hasyim Asy'ari Tebuireng, Jombang, Indonesia \\ e-mail : surga129ie@gmail.com \\ ${ }^{2}$ Teknik Industri, FakultasTeknik \\ Universitas Maarif Hasyim Latif, Sidoarjo, Indonesia \\ e-mail : prasnowoadhi@dosen.umaha.ac.id \\ Diterima: 1 April 2017. Disetujui : 24 Mei 2017. Dipublikasikan : 1 Juni 2017 \\ (C)2017 -TESJ Fakultas Teknik Universitas Maarif Hasyim Latif. Ini adalah artikel dengan \\ akses terbuka di bawah lisensi CC BY 4.0 (https://creativecommons.org/licenses/by/4.0/)

\begin{abstract}
ABSTRAK
Langkah perancangan produk merupakan faktor penting dalam menghasilkan penentuan yang akan dicapai oleh tim desainer. Pada langkah penelitian ini perancangan produk terdiri dari. : (1) Fase Perencanaan (2) Fase Pengembangan Konsep (3) Fase Perancangan Tingkat Sistem (4) Fase Perancangan Detail (5) Fase Pengujian dan Perbaikan (6) Fase Produksi. Pada tahap perancangan kemudian muncul 2 alternatif konsep. Konsep 1 adalah alat dengan mekanisme otomatis memanfaatkan motor listrik sedangkan konsep 2 adalah mekanisme otomatis menggunakan hidrolis angin. Pada tahap pemilihan konsep dipilih konsep 1 menggunakan metode binary dominance matrix dengan prosentase bobot 85,32959\%. Setelah konsep dipilih dan produk geometris dirancang kemudian dilanjtkan dalam tahap pengujian dan perbaikan, produk di realisasikan dan diuji dengan kapasitas potong 1473 unit / jam orang dan telah mampu memotong 2 lapisan bahan setebal $6 \mathrm{~mm}$. Tahap akhir adalah membandingkan hasil perancangan dengan alat lama, pada tahap proses pembandingan ini dilakukan dengan metode sebagai berikut: (a) NPV, (b) PPA, (c) stop watch time study. Didapat hasil bahwa secara keseluruhan lebih banyak keuntungan alat baru dibandingkan dengan alat yang lama, dengan hasil perhitungan PV sebesar Rp. 2.072.996.438,54, PPA 0,01405 tahun, kapasitas potong satu setara dengan 5 alat lama yaitu 2496 unit / jam /orang dan posisi operator yang lebih nyaman dengan duduk.
\end{abstract}

Kata kunci: Perancangan dan Pengembangan Produk, Voice of Customer, Ergonomi, Binary Dominance Matrix, Stop watch time study, NPV, PPA.

\section{PENDAHULUAN}

Upaya untuk mengikuti perkembangan yang semakin meningkat pelaku usaha yang semula hanya berskala rumah tangga dalam berproduksi dan menggunakan peralatan seadanya, perlahan mulai mengganti peralatan produksi menjadi yang lebih berteknologi sebagai upaya untuk meningkatkan jumlah produksi agar bisa memenuhi permintaan pasar. Dari permasalahan inilah penelitian ini mencoba untuk memberikan alternatif solusi permasalahan yang ada dengan merancang dan mengembangkan alat produksi baru, berupa alat potong sol sandal dengan mekanisme kerja otomatis karena dengan mekanisme kerja otomatis sistem kerja akan lebih efektif dan efisien sehingga kapasitas pemotongan bisa lebih banyak dan tetap dengan memperhatikan harga alat yakni dengan range Rp.6-8 juta, agar alat bisa terjangkau oleh para pelaku usaha kelas menengah.

\section{METODE PENELITIAN}

\section{Perancangan dan Pengembangan Produk}

Banyak literatur yang telah mencoba menjabarkan tentang perancangan dan bagaimana definisi tentang perancangan itu sendiri, perancangan (design) merupakan suatu kegiatan atau rekayasa rancang bangun yang dimulai dari ide-ide inovasi desain, atau kemampuan untuk menghasilkan karya dan cipta yang benar-benar dapat menjabarkan permintaan pasar karena adanya penelitian dan pengembangan teknologi (Prasetyowibowo, 2000).

Definisi desain menurut kamus umumnya adalah membuat suatu rencana (to fashion after plan). Selanjutnya adalah kombinasi definisi baik untuk proses maupun praktisnya yang diambil dari institusi Inggris Institution of Engineering Designers dan organisasi dosen desain teknik, SEED Ltd. Desain teknik adalah seluruh aktivitas untuk membangun dan mendifinisikan 
berbagai solusi bagi masalah-masalah yang ada, yang tidak dapat dipecahkan sebelumnya atau solusi baru bagi berbagai masalah yang sebelumnya telah dipecahkan tetapi dengan cara berbeda. Aktivitas desain belum bisa dikatakan selesai sebelum hasil akhir produk dapat dipergunakan dengan tingkat performa yang dapat diterima dan dengan metode kerja yang terdefinisi dengan jelas. Fase-fase dalam perancangan dan pengembangan produk antara lain : (1) Fase Perencanaan (2) Fase Pengembangan Konsep (3) Fase Perancangan Tingkat Sistem (4) Fase Perancangan Detail (5) Fase Pengujian dan Perbaikan (6) Fase Produksi.

\section{Uji Kecukupan dan Keseragaman Data}

Uji kecukupan data adalah bentuk pengujian statistik, yang berfungsi untuk menganalisa data kuesioner yang diberikan telah cukup menggambarkan populasi pelanggan keseluruhan. Selain kecukupan data harus dipenuhi dalam pelaksanaan time study maka yang tidak kalah pentingnya adalah bahwa data yang diperoleh haruslah juga seragam. Tes/uji keseragaman data perlu dilakukan terledih dahulu sebelum kita menggunakan data yang diperoleh guna menetapkan waktu standar. Tes keseragaman data bisa dilaksanakan dengan cara visual dan atau mengaplikasikan peta kontrol (control chart). Peta kontrol (control chart) adalah suatu alat yang tepat guna dalam menguji keseragaman data yang di peroleh dari hasil pengamatan.

\section{Uji Validitas dan Reliabilitas}

Validitas menunjukkan sejauh mana skor/ nilai/ ukuran yang diperoleh benar-benar menyatakan hasil pengukuran/ pengamatan yang ingin diukurdengan hasil pengukuran psikologis atau non fisik. Reliabilitas merupakan indeks yang menunjukkan sejauh mana suatu alat pengukur dapat dipercaya atau dapat diandalkan (Singarimbun, 1989). Setiap alat pengukur seharusnya memiliki kemampuan untuk memberikan hasil pengukuran relatif konsisten dari waktu ke waktu. Dalam penelitian ini uji yang digunakan adalah dengan cara membandingkan nilai alfa cronbachs dengan nilai $r$ pada tabel.

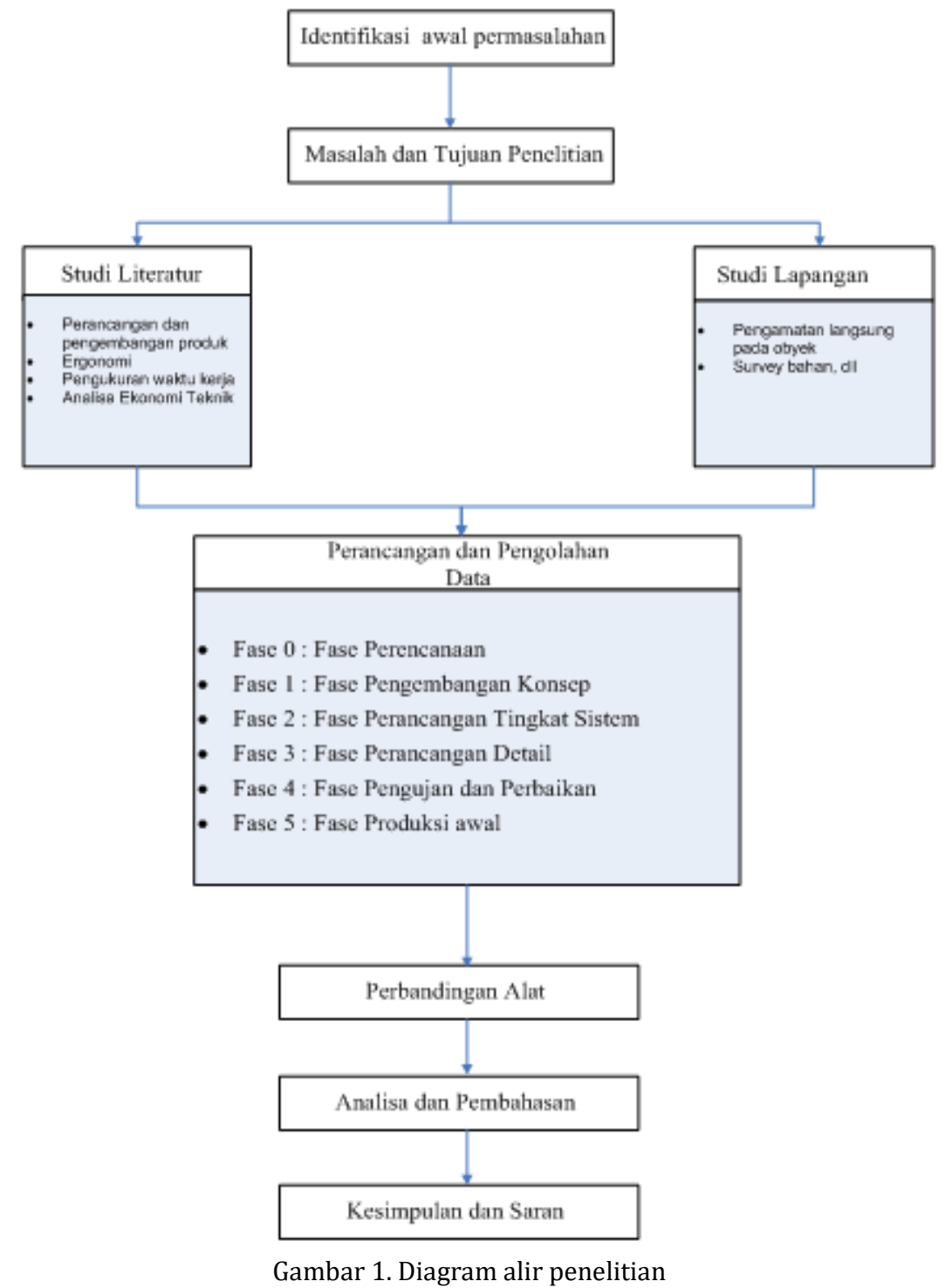




\section{Pengukuran Waktu Kerja dengan Jam Henti (Stop Wacth Time Study) \\ Pengukuran waktu kerja dengan jam henti (Stop} Wacth Time Study) diperkenalkan pertama kali oleh Frederick W. Taylor sekitar abad 19 yang lalu. Metoda ini terutama sekali baik diaplikasikan untuk pekerjaanpekerjaan yang berlangsung singkat dan berulang-ulang (repetitive). Dari hasil pengukuran maka akan diperoleh waktu baku untuk menyelesaikan waktu siklus pekerjaan, yang mana waktu ini akan dipergunakan sebagai standar penyelesaian pekerjaan bagi semua pekerja yang akan melaksanakan pekerjaan yang sama seperti itu.

\section{Net Present Value (NPV)}

NPV didefinisikan sebagai nilai dari proyek yang bersangkutan yang diperoleh berdasarkan selisih antara cash flow yang dihasilkan terhadap investasi yang dikeluarkan. NPV yang layak adalah NPV positif, dimana ini berarti cash flow yang dihasilkan melebihi jumlah yang diinvestasikan (Joesron,2001).

Perhitungan nilai NPV adalah dengan mendiskontokan semua arus kas masuk dan arus kas keluar selama umur proyek (investasi) ke nilai sekarang (Present value), kemudian dihitung selisih nilai sekarang dari arus masuk dan arus keluar. NPV menunjukkan jumlah Lump sum, yang dengan arus diskonto tertentu (WACC) memberikan angka seberapa besar nilai usaha (Rp) tersebut pada saat ini (Gunarta,2006).

Jika nilai dari NPV dari sebuah proyek adalah negatif, maka proyek tersebut dapat dikatakan tidak layak karena jumlah pengeluaran melebihi dari nilai investasi dan hal ini menunjukkan bahwa cash flow dari proyek tersebut cukup untuk membayar modal investasi. Jika nilai investasi positif, maka cash flow proyek tersebut memperlihatkan adanya keuntungan dan semenjak nilai pengembalian untuk para pemegang saham. Untuk itu, jika perusahaan akan melakukan proyek dengan nilai NPV nol maka posisi para pemegang saham akan tetap. Perusahaan akan menajdi lebih besar tapi nilai saham tidak berubah. Sedangkan jika perusahaan mengambil proyek dengan nilai NPV positif, posisi dari para pemegang saham akan meningkat.

\section{Payback Period Analysis}

Analisis Payback Period menghitung waktu yang diperlukan arus kas masuk sama dengan arus kas keluar. Analisis itu biasanya digunakan untuk mengukur tingkat resiko alternatif, berkaitan dengan seberapa cepat nilai investasi dapat dikembalikan. Alternatif dengan periode pengembalian yang lebih singkat merupakan pilihan yang lebih menarik.

Adapun metode penelitian yang digunakan seperti pada Gambar 1.

\section{HASIL DAN PEMBAHASAN}

Dari hasil pengolahan yang dilakukan dalam penelitian perancangan dan pengembangan alat potong sol sandal ditampilkan pada Gambar 2 dan Tabel 1 .
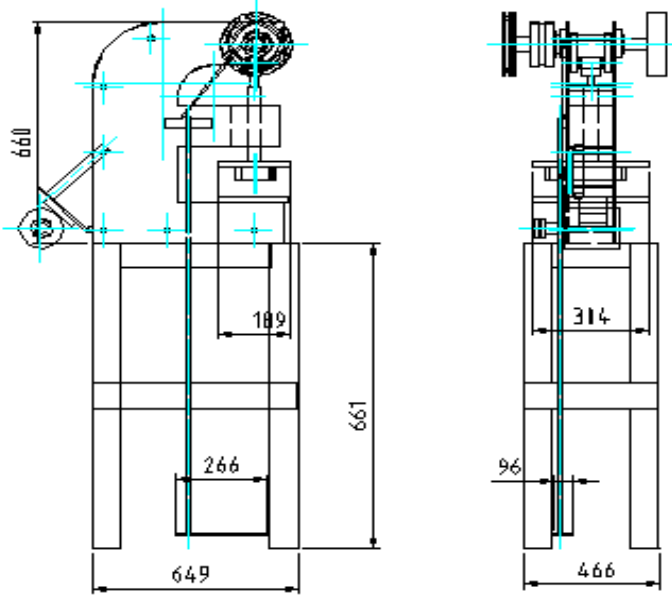

Gambar 2. Alat potong sol sandal baru

Tabel 1. Perbandingan Alat

\begin{tabular}{|l|l|l|}
\hline \multicolumn{1}{|c|}{ KETERANGAN } & \multicolumn{1}{|c|}{ ALAT LAMA } & \multicolumn{1}{c|}{ ALAT BARU } \\
\hline Posisi Operator & Berdiri & Duduk \\
\hline $\begin{array}{l}\text { Kapasitas } \\
\text { Pemotongan }\end{array}$ & 602 pieces/hari & $\begin{array}{l}\text { 2946 pieces/hari } \\
\text { Setara dengan kapasi- } \\
\text { tas } \pm 5 \text { buah alat lama }\end{array}$ \\
\hline $\begin{array}{l}\text { Kapasitas tebal } \\
\text { bahan }\end{array}$ & 1 lapis & 2 lapis \\
\hline Elemen kerja & 4 elemen & 3 elemen \\
\hline Mekanisme Kerja & Manual & Otomatis \\
\hline PPA & 0,02377 tahun & 0,01405 tahun \\
\hline NPV & $369.168 .788,147$ & $2.072 .996 .438,54$ \\
\hline
\end{tabular}

Jadi dapat ditarik kesimpulan bahwa alat baru lebih menguntungkan dibanding alat lama.

\section{PENUTUP}

Berdasarkan pengolahan data dan analisa yang dilakukan, terdapat beberapa poin penting yang dapat ditarik sebagai kesimpulan dari penelitian ini di antaranya :

1. Keinginan pelaku usaha pembuatan sandal untuk merubah alat manual menjadi sistem otomatis, yang ditunjukkan dari hasil kuisioner yang disebarkan kepada 32 responden.

2. Konsep terbentuk dengan rancangan alat otomatis.

3. Dari hasil pembentukan konsep akhirnya terpilih konsep alat potong sol sandal dengan penggerak pemotong menggunakan motor listrik.

4. Pengurangan elemen kerja. 
5. Dari hasil perhitungan NPV, alternatif alat baru lebih menguntungkan.

6. Dari hasil perhitungan PPA, alternatif alat baru lebih menguntungkan.

\section{DAFTAR PUSTAKA}

Hurst, K. (2006). Prinsip - Prinsip Perancangan Teknik. Erlangga. Jakarta.

Nurmianto, E. (2004). Ergonomi Konsep Dasar dan Aplikasinya. Edisi Kedua. Penerbit Guna Widya, Institut Teknologi Sepuluh Nopember. Surabaya.

Pheasant, S. (1986). Body space : Anthropometri, ergonomics and desain. London : Taylor and Francis.

Prasetyowibowo, B. (2000). Evaluasi Ergonomis dalam Desain, FTSP - FTI. ITS. Surabaya.

Soetedja, A. (2000). Pengaruh Persepsi Kesehatan dan Keselamatan Kerja pada Karyawan Terhadap Peningkatan Kinerja . Seminar Nasional Ergonomi, FTSP - FTI. ITS. Surabaya.
Sugiyono. (2006). Statistika Untuk Penelitian cetakan ke-sembilan, CV. Alfabeta. Bandung.

Ulrich, K.T. and Eppinger, S.D. (2001). Perancangan dan Pengembangan Produk. McGraw-Hill, Inc., New York.

Wignjosoebroto, S. (1995). Ergonomi, Studi Gerak dan Waktu. Teknik Analisis Untuk Peningkatan Produktivitas Kerja. Guna Widya, Institut Teknologi Sepuluh Nopember. Surabaya.

Wignjosoebroto, S. (2000). Evaluasi Ergonomis Dalam Proses Perancangan Produk, FTSP FTI. ITS. Surabaya. 